\title{
Threshold Effect of Foreign Direct Investment on Economic Growth: New Evidence From a Panel Regime Switching Models
}

\section{Maha Kalai ( $\sim$ maha.kalai@fsegs.usf.tn )}

Université de Sfax Faculté des Sciences Economiques et de Gestion de Sfax: Universite de Sfax Faculte des Sciences Economiques et de Gestion de Sfax https://orcid.org/0000-0002-6770-6599

\section{HELALI Kamel}

Université de Sfax Faculté des Sciences Economiques et de Gestion de Sfax: Universite de Sfax Faculte des Sciences Economiques et de Gestion de Sfax

\section{Research}

Keywords: Foreign direct investment, Economic growth, Panel Regime Switching model, Arab Maghreb Union

Posted Date: February 15th, 2021

DOl: https://doi.org/10.21203/rs.3.rs-167596/v1

License: (a) This work is licensed under a Creative Commons Attribution 4.0 International License. Read Full License 


\title{
Threshold effect of foreign direct investment on economic growth: New evidence from a panel regime switching models
}

\section{Title Page}

\author{
Maha KALAI * \\ Faculty of Economics and Management of Sfax, University of Sfax \\ Address: Aerodrome road km 4.5, B.P. 1088-3018, Sfax, Tunisia. \\ Laboratory: Research Laboratory in Competitiveness, Commercial Decisions and Internationalisation (CODECI). \\ E-mail address: maha.kalai@fsegs.usf.tn \\ Telephone number: +21621790605 \\ (*) Corresponding author
}

\section{Kamel HELALI}

Faculty of Economics and Management of Sfax, University of Sfax

Address: Aerodrome road km 4.5, B.P. 1088-3018, Sfax, Tunisia.

Laboratory: Research Laboratory in Competitiveness, Commercial Decisions and Internationalisation (CODECI).

E-mail address: kamel.helali@fsegs.usf.tn

Telephone number: +21698667705 


\title{
Threshold effect of foreign direct investment on economic growth: New evidence from a panel regime switching models
}

\begin{abstract}
The article contributes to the existing literature by examining the non-linear effect of foreign direct investment (FDI) on the development of the Arab Maghreb Union (AMU) countries during the period 1980-2019. These countries multiply their FDI attraction policies in order to enrich the national externalities offered to local businesses and benefit from some positive effects on their economy in terms of growth, technology, know-how, etc. Using Panel Smooth Transition Regression Model (PSTR) and Panel Smooth Transition Autoregressive Model (PSTAR) models, our findings reveal that the FDI shows opposite effects below and over the estimated threshold. This highlights the asymmetrical effect of unforeseen shocks on its volatility. Policy implications are also discussed.
\end{abstract}

Keywords: Foreign direct investment; Economic growth; Panel Regime Switching model; Arab Maghreb Union.

JEL Classification: C51; C53; F21; F21; F34; O16; O23; R11. 


\section{Introduction}

In a broader context of globalization, economies have experienced rapid growth in international trade and capital flows. As a result, economies around the world are now more closely integrated. Since the beginning of the 1980s, with the acceleration of the process of globalization, foreign direct investment (FDI) has been growing at a phenomenal rate. It contributes mainly to the process of global industrial restructuring and is also one of the most dynamic elements of international transactions. Indeed, given the interest in direct investment flows abroad, the issue of relocation is at the heart of the economic and social debate, worldwide. However, over the last two decades, the evolution of FDIs globally has been on a steady increase. The volume of FDI flows has increased, but both sending and receiving countries have diverse reasons.

To increase their investment capacity, compensate for the insufficiency of national savings, create new opportunities for quality jobs offering better remuneration or better working conditions, the Mediterranean countries are trying to make the FDIs one of the most powerful pillars in the development strategy of the Mediterranean zone, including the Arab Maghreb Union (AMU) countries. However, the overall FDI volume in the region is very low (1.8\% of GDP). These results, unfortunately, are far from the expectations of the populations, on the one hand, and the potential offered by the region, on the other hand. These results, or rather these failures, could be attributed to three essential factors: the primacy of politics over economics, verticality and the economic and financial dependence of the EU, and the lack of vision, strategy and planning. The AMU countries have focused their actions on economic and social recovery considering FDIs as a by-product of economic development, which explains the great importance attributed to the attractiveness of foreign investment flows, by adopting a series of measures to make the region more and more attractive.

Almost all the AMU countries are now trying to attract FDI through various and varied "incentive measures", such as macroeconomic stabilization, exchange rate policies and the signing of partnership agreements with Europe, tax exemption or the establishment of free zones, privatization sanctioning the withdrawal of the State from certain sectors of activity, or institutional reforms aimed at improving the business climate. The range of incentives is now large and relevant, after the 1995 Euro-Mediterranean agreements, also known as the Barcelona Process and the start of attractiveness policies in the area, to question the effectiveness of these measures in terms of growth. According to Giovannetti and Ricchiuti (2008), there is little empirical evidence that supports the hypothesis of the positive effect of FDI on growth for the southern Mediterranean countries. The authors explain this lack of certainty by the low level of FDI in absolute terms and relative to GDP, and by the structural weaknesses of growth in these countries.

A short while ago, the economic and financial sphere has been characterized by numerous stock market crashes and financial crises. This instability is often seen as the main source of very persistent fluctuations and volatilities in the financial markets. In fact, it is on the basis of these irregularities that Richard Godwin (1991), one of the pioneers of nonlinear dynamic models in economics, formed his reflection, which comes from the observation of a persistence of instability, fluctuations, turbulences, unpredictability and a-periodicity observed on the financial markets. This new perception of economic phenomena seems to escape any type of classical modeling. Taking into account the non-linearity and more specifically the existence of regime change phenomena has for some time been changing deeply the approaches of econometrics applied to macroeconomics and finance.

An extensive research has debated the non-linear impacts of FDI on economic growth. For instance, Kottaridi and Stengos (2010) made a new contribution to the literature on the link between FDI flows and economic growth. By taken into account the non-linear effects of initial income and human capital on growth, the authors found that FDI inflows have consolidated economic growth in middle-income countries, compared to culminating income-producing countries which have undergone two distinct regimes of FDI flows in their development. 
Therefore, it is important to see whether these FDI flows adjustments have really contributed to the AMU economic growth. In this context, the main contribution of this article is to explain the asymmetry of FDI impact on economic growth for the AMU countries using a panel regime switching models during the period 1980-2019. The major question is whether the volatility of FDI contributes to the improvement of economic growth in the host countries. Moreover, the study also seeks to measure the rate of adjustment of FDI towards its equilibrium levels, which justifies the use of non-linear modelling approach. More specifically, testing the existence of a non-linear relationship between economic growth and FDI through the explanation of the asymmetry of the impact (mixed relationship, sometimes positive and sometimes negative) of FDI on economic growth for developing countries, especially for AMU countries. In this context, if we use linear models, we quickly conclude that their forecasting capacities are very limited. It suffices to remember the failure of the forecasts for the stock market crash of 1987, also of the repercussions of the Asian crises of 1997-1998 or of the financial crises of 2002 and 2007. This lack of forecasting capacity, whether during variations the price of financial assets or exchange rates leads to the search elsewhere for other types of modeling that allow us to obtain these forecasts.

The rest of the article is structured as follows. Section 2 presents the literature review while Section 3 explains the empirical strategy and data. Section 4 reports and discussed the empirical findings. Conclusions and implications are presented in Section 5.

\section{Literature review}

Several studies have shown how host countries benefit from the flows of FDI, especially in terms of economic growth mainly through the transfer and diffusion of technology from technologically developed countries to non-developed countries. Thus, technological progress is a growing function of technological backwardness. As a result, FDI can spread to the entire local economy of a country and affect its economic growth through diffusion mechanisms known as "spillovers" or positive externalities (Kokko, 1996; Borensztein et al., 1998; Blomström et al., 1999; Girma and Görg, 2005; Athreye and Cantwell, 2007; Fu, 2008; Farkas, 2012; Khordagui and Saleh, 2013). For instance, using data for data from 69 developing countries, Borensztein et al. (1998) have found that FDI flows are very important for both technology transfer and economic growth. For their part, Mallampally and Sauvant (1999) testified that FDI has become an effective means of foreign financing for the developing economies in the way that it can have several effects on their economies (on growth, human capital, trading structure, etc.).

Based on an endogenous growth model created from a sample of 24 Chinese provinces during the 1985-1996 period, Berthélemy and Démurger (2000), supported that the transfer of foreign technology through "FDI Spillovers" is a key determinant of provincial economic growth of the People's Republic of China. Using a panel of 12 Latin American countries between 1950 and 1985 and annual data on a group of 85 developing countries covering Asia, Africa, Latin America and the Caribbean for the period 1980-2007, De Gregorio (1992) and Ekanayake et al. (2010), agreed on a significant positive relationship between foreign investment and the economic growth of the countries in the study. However, increasing these flows is not a guarantee to reduce poverty and maintain the positive effects on growth. For FDI to spread technology transfer spillovers and push the economic growth of a developing country, two conditions must be met. Firstly, the developing countries must be attractive to investors and secondly, their environments must be timely to absorb the effects of modern technology. According to an empirical macroeconomic study based on the theoretical model of Agosin and Mayer (2000), Lahimer (2009) examined the relationship between FDI and domestic investment (DI) based on a sample of 42 sub-Saharan African countries over the period from 1990 to 1995. The results showed that the effect of FDI on DI is positive, significant and fixed. In other words, a one-point increase of FDI implies a concomitant increase of DI between 0.10 and 0.13 points.

In a study of selected OECD and non-OECD countries between 1970-90, De Mello (1999) found a complementary relationship between FDI flows and DI. On their part, Kottaridi and Stengos (2010) 
made a new contribution to the existing literature on the link between FDI flows and economic growth. Using empirical evidence that takes into account the non-linear effects of initial income and human capital on growth, the authors concluded that FDI inflows have strengthened the economic growth of the middle-income countries, as opposed to high-income ones that have undergone two distinct regimes of FDI flows on their development.

Regarding the AMU region, Zenasni and Benhabib (2013) studied the determinants of FDI and empirically examined their impacts on economic growth in three Maghreb countries (Algeria, Morocco, and Tunisia) during the period 1980-2010. Using a dynamic panel GMM estimator, their empirical investigation suggested that, under particular economic and financial conditions, FDI positively affects the growth rate in the long run and improves the economic situation in the AMU countries. Recently, Carbonell and Werner (2018) showed that FDI rose significantly, and Spain offered ideal conditions for FDI to unfold its hypothesized positive effects on economic growth. Their results are robust and showed that the favorable Spanish circumstances provided no evidence that FDI stimulates economic growth. Moreover, the Spanish entry into the EU was also found to have no positive effect on economic growth. These findings call for a fundamental rethinking of methodology in economics.

In summary, these empirical studies are unanimous on the fact that FDI has undeniable advantages for the host country in terms of externalities, besides their effects on growth are direct and unconditional because of the existence of a technological gap between the foreign investor and the host country. However, the channels of diffusion of these externalities, as described, raise doubts as to the systematic and direct effect of FDI. In order to be able to assimilate foreign technologies and create local dynamics within and between sectors, it is necessary for the host country to have a minimum threshold of qualifications and skills enabling local employees to understand these technologies and disseminate them (Borensztein et al., 1998; Ben Abdallah and Meddeb, 2001). The existence of a minimum threshold of structural, institutional and economic factors that drive FDI to contribute to the growth of a developing country has been highlighted in several empirical studies (Ben Abdallah and Meddeb, 2001; Carkovic and Levine, 2002; Krogstrup and Matar, 2005; Farkas, 2012; Kalai and Zghidi, 2019). Therefore, our work focuses on these specific factors, such as the level of education of the workforce, the level of infrastructure and the institutional development, which do not necessarily condition the implementation of FDI but curb its externalities (Kokko, 1994; Blomström and Wolf, 1994; Li and Liu, 2005). In this sense, human capital is a factor that locates FDI coming from multinational firms (Bas and Sierra, 2002). Fu (2008) stated that the technological intensity of FDI in the host country would benefit from spillovers in terms of the generated links. This effect is complemented by the existence of sufficient local skills and technological knowledge to capture the benefits of FDI (Farole and Winkler, 2012). On the other hand, when the "technology gap" is large, the host country would find it difficult to develop the human capital and the learning needed to benefit from the effects of FDI in terms of spillovers (Girma and Görg, 2005). Therefore, a set of initial conditions present in the host country is then necessary to take advantage of the extent of the effects of FDI on a dynamic growth perspective. This set of factors is the absorptive capacity of a country (Farkas, 2012).

AfDB's (2015) empirical results of the regression regarding the impact of FDI on the well-being in North Africa by taking the Human Development Indicator (HDI) as a welfare-dependent variable show that the relationship between the well-being and FDI can be nonlinear. Indeed, the results also indicate that FDI has a positive impact on the well-being at a significance level of $1 \%$ in North Africa and that the relationship seems non-linear. These findings differ slightly from those of Gohou and Soumare (2012) for North Africa, who found that the link between FDI and HDI is not significant. This can be explained, in the first place, by the fact that the authors did not take into account the non-linear nature of this relationship. Indeed, the FDI coefficient is not significant, as in Gohou and Soumaré (2012), but when we introduce the non-linearity while keeping the same logarithm, the coefficient becomes significant. 


\section{Empirical strategy}

About twenty years after the first academic studies initiating this movement, the robustness was reflected in the fact that there is very little research that took into account the nonlinearity and more exactly the switching regression model in panel. The threshold regressions in panel data models allow modeling the heterogeneity of the slope parameters. These models give a parametric approach of the heterogeneity which is associated to an economic story. Mainly, two forms of relaxing modeling on these specific ones have been treated in the literature. They are differentiated by their transition function. The first, which is the Panel Threshold Regression Model (PTR) developed by Bruce Hansen (1999), has the same transition function as a Threshold Autoregressive Model (TAR). This approach therefore favors the generation, on a given date, of sub-sets of homogeneous units with the same behavior. Conversely, the second approach, which is the Panel Smooth Threshold Regression Model (PSTR) model developed by González et al. $(2005,2017)$ and based on a smooth transition function, belongs to the group of time-amplified STAR models. By definition, in this approach, which contains an infinite set of regimes, all the units can be determined by a dissimilar dynamics. In this context, Fok et al. (2005) proposed another class of smooth transition threshold models, which is the class of the Panel Smooth Transition Autoregressive model (PSTAR) that helps use an autoregressive structure. In this paper, we try to employ the two models: PSTR and PSTAR.

\subsection{The PSTR model}

González et al. $(2005,2017)$ recommended a strengthening of the PTR models through the Panel Smooth Transition Regression Model (PSTR) approach (see Ben Cheikh and Ben Zaied, 2020). The contribution of this model is similar to the one used in switching from brisk transition approaches to smooth transition approaches in time series.

Therefore, the process $\left(y_{i t}, t \in Z\right.$ and $\left.i \in Z\right)$ satisfies a two-regime PSTR model, if and only if:

$$
y_{i t}=\mu_{i}+\beta_{0}^{\prime} X_{i t}+\beta_{1}^{\prime} X_{i t} G\left(q_{i t} ; \gamma, c\right)+\varepsilon_{i t}
$$

where $\mu_{i}$ is the vector of the individual fixed coefficients, $G\left(q_{i t} ; \gamma, c\right)$ denotes the transition function relative to the transition variable $q_{i t}$, at threshold parameter $c$ and a smoothing coefficient $\gamma$. $X_{i t}=\left(X_{i t}^{1}, \ldots, X_{i t}^{k}\right)$ is the matrix of $k$ exogenous variables that do not contain lagged explanatory variables, $\beta=\left(\beta_{1}, \ldots, \beta_{k}\right)$ and $\varepsilon_{i t}$ is $\operatorname{iid}\left(0 ; \sigma_{\varepsilon}^{2}\right)$. The index $i=1, \ldots, N$ refers to the individual dimension and the index $t=1, \ldots, T$ to the temporal dimension.

Like the time series development, the indicator function of the PTR modeling is modified by a continuous transition function $G\left(q_{i t} ; \gamma, c\right)$ differentiable over the interval 0 and 1 . This transformation allows the transition of the process slowly from one regime to another. We can then consider two explanations of the PSTR model. It can be first contemplated as an approach containing an unlimited number of regimes circumscribed by two extreme ones. For a model in linear and heterogeneous panel data, we interpret the coefficients that can change according to the units and the considered date. The second seeks to comment on the PSTR approach as a nonlinear model, where the process slowly changes between two linear and homogeneous extreme regimes.

Ideally, a transition function between regimes can be specified from different transition functions, which are continuous and derivable on $[0,1]$. In this context, González et al. $(2005,2017)$ recommended to set a logistic shift function of order $m$ :

$$
G\left(q_{i t} ; \gamma, c\right)=\left[1+\exp \left(-\gamma \prod_{j=1}^{m}\left(q_{i t}-c_{j}\right)\right)\right]^{-1}, \gamma>0, c_{1}<\ldots<c_{m}
$$

where $c=\left(c_{1}, \Lambda, c_{m}\right)$ is a dimension vector $(1, m)$ containing the threshold coefficients and $\gamma$ symbolizes the presumed positive coefficient. 
It is therefore better to be interested in: (i) the signs of slope parameters $\beta_{1}$ which represent whether the relationship between the exogenous and endogenous variables increases or decreases as a function of the transition variable; (ii) the temporal evolution of the slope parameters; (iii) the marginal effect of exogenous factors $X_{i t}$ on the endogenous variable $y_{i t}$ :

$$
\frac{\delta y_{i t}}{\delta X_{i t}}=\beta_{0}+\beta_{1} G\left(q_{i t} ; \gamma, c\right)
$$

Moreover, the "U" shape of this function (see Fouquau, 2008) means that the extreme regimes placed on either side of the threshold coefficients are similar and distinct from the centrally located extreme regime for $q_{i t}=\left(c_{1}+c_{2}\right) / 2$. For this reason, the dynamics in the extreme regimes spaced from the limits is thus painted by the total of the parameters $\beta_{0}+\beta_{1}$, while in the central regime, it is painted by the total of the coefficients $\beta_{0}$ and $\beta_{1}$, moderated by a constant value of the transition function included between 0 and $1 / 2$. In fact, the speed of change between the two regimes depends relentlessly on the value of the smoothing parameter. When $\gamma$ goes to infinity, the PSTR model corresponds to a three-regime PTR model where the external regimes are similar and distinct from the central one. On the other hand, when $\gamma$ tends towards zero, the PSTR model is degraded into a homogeneous model with fixed effects. This is clear in equation (2) where the result is examined for any value of $m$.

Usually, in time series, the solution is to use the logistic change function or the exponential function proposed by Teräsvirta and Anderson (1992) in the STAR models. Nevertheless, this function was not used in panel data with the exception of the work of Bessec and Fouquau (2008). This lack of interest can be interpreted by the neighborhood between the exponential function form and the order 2 logistic function. However, the exponential shift function has the privilege of being more observant, demanding the estimation of only one threshold, as shown in equation (4):

$$
G\left(q_{i t} ; \gamma, c\right)=1-\exp \left[-\gamma\left(q_{i t}-c\right)^{2}\right], \quad \gamma>0
$$

We notice the $U$ configuration, which means that the function tends to 1 when the transition parameter $q_{i t}$ deviates from the threshold parameter $c$, and conversely, it tends to 0 for $q_{i t}=c$, which not the case with the 2 nd order logistic function. Here, the process obeys the same dynamics associated with the slope coefficients $\beta_{0}^{\prime}+\beta_{1}^{\prime}$. In fact, when the values of $q_{i t}$ are equal to the threshold, the dynamics is traced using the parameter $\beta_{0}$. On the other hand, when the smoothing coefficient $\gamma$ tends to zero or towards infinity, the exponential form becomes fixed (respectively equal to 0 and 1), and the PSTR approach becomes a linear model with individual effects and not a three-regime PTR model.

\subsection{The PSTAR model}

The PSTAR specification developed by Fok et al. (2005) helped to expand the review framework by preparing threshold modeling on panel data with an autoregressive structure. The shape of this model is close to that of a PSTR model with a single transition function. This modeling has been recommended by Fok et al. (2005) and used for premonition purposes on the production of manufacturing sectors in the United States.

Hence, the process $\left(y_{i t}, t \in Z\right.$ and $\left.i \in Z\right)$ satisfies a two-regime PSTAR model, if and only if:

$$
y_{i t}=\alpha_{i, 0}+\sum_{j=1}^{P_{i}} \alpha_{i, j} y_{i, t-j}+G\left(q_{t} ; \gamma_{i}, c_{i}\right)\left(\beta_{i, 0}+\sum_{j=1}^{P_{i}} \beta_{i, j} y_{i, t-j}\right)+u_{i t}
$$

where $\alpha_{i, 0}$ represents the individual fixed effects, $P_{i}$ denotes the order of the autoregressive process and $G\left(q_{t} ; \gamma_{i}, c_{i}\right)$ the transition function relative to common factor $q_{t}$, coefficients of thresholds $c_{i}$ and smoothing $\gamma_{i}$ individual for $i=1, \ldots, N$. The residuals are assumed to have zero conditional expectation $E\left[u_{i t} \mid \Omega_{i t}\right]=0$ where $\Omega_{i t}=\left(y_{i, t-1}, \Lambda, y_{i, t-p}, \Lambda\right)$ and a constant conditional variance, 
$E\left[u_{i t}^{2} \mid \Omega_{i t}\right]=\sigma_{i}^{2}$. Moreover, it is generally claimed that the error terms are not correlated with each other either in the temporal or in the individual dimension.

Equation (5) admits a smooth transition between the extreme regimes that are conditional on each unit. Indeed, the parameters $\alpha_{i}$ and $\beta_{i}$ depend on the units reciprocal to the PSTR model. On the other hand, there is no reason to force the autoregressive order $P_{i}$ to be the same for all the units, yet, for a given unit, it is assumed to be similar in the two extreme regimes.

In the determination of the PSTAR approach, the assumption of uncorrelated residues between them can be suspended by accepting the union of different forms of covariance. However, according to Fok et al. (2005), this procedure greatly confuses the estimation phase of the coefficients. An alternative result helping admit contemporary correlations between the errors consists in introducing common explanatory variables $z_{1, t}, \ldots, z_{k, t}$ as complementary exogenous factors. It should be called that in the PSTAR model, Fok et al. (2005) argued that the transition function between regimes is carried out using a first-order transition mechanism, the specificities of which have been described in the previous sub-section:

$$
G\left(q_{i t} ; \gamma_{i}, c_{i}\right)=\frac{1}{1+\exp \left[-\gamma_{i}\left(q_{i t}-c_{i}\right)\right]}, \quad \gamma_{i}>0
$$

In the above function, the transition parameter $q_{t}$ is assumed to be common for all the units so, it is essential to prefer an indicator that does not depend on the individual dimension but may generate a pass function for all the units. Thus, if the limit and smoothing coefficient are assumed to be similar then, the transition function will be much the same for all the units. Nevertheless, this presentation is less realistic when the number of units increases. For this reason, Fok et al. (2005) assumed that the threshold and smoothing coefficients change according to the concerned unit $c_{i} \neq c_{j}$ and $\gamma_{i} \neq \gamma_{j}$ for $i \neq j$ where $i$ and $j=1, \ldots, N$. Economically speaking, this alternative has the privilege of being able to generate the basic intuition underlying the operation of "contagion".

\subsection{Presentation of the variables, model and the sample}

The purpose of this sub-section was to describe the sample and the variables analysis of each country in the sample. In fact, our panel comprises $\mathrm{N}=5$ Maghreb countries, namely Algeria, Morocco, Mauritania, Libya and Tunisia, between 1980 and 2019, that is 40 observations per country. Indeed, and based on the statistics presented in Table 1 below, we described the main characteristics of the main variables used in this study. Data are collected from the World Bank 2020 database and the central banks of Tunisia, Morocco, Algeria, Mauritania and Libya.

Gross domestic product per capita (GDPC) is the indicator of the level of economic activity employed. It is more effective than GDP in measuring the development of AMU countries. In Solow's model (1956), the increase in the production factors (labor and capital) accounts for some of the growth. It is thanks to the increase in paid employment (labor factor) and domestic investment (capital factor) that there is growth. However, most of the growth is not explained by these two factors, but rather through a residual factor. In other words it is the technical progress, which origin is not really known (some say it is a factor that "fell from the sky"). The causes of growth (population increase and technical progress) are therefore exogenous: the model does not explain their origin. In addition to labor (salaried employment, POP) and capital (Gross Fixed Capital Formation, GFCF as a percentage of GDP), the other explanatory variables can be presented in three groups. These variables are different in nature and act differently on growth. Still, this step is obligatory to carry out the estimation.

Our approach consists to use three groups of variables and carried out our estimation over the data collected between 1980 and 2019. What made our estimation technique effective was the use of such criteria as absence of autocorrelation of residues and individual and temporal heteroskedasticity. Indeed, the first group of explanatory variables forms those related to the 
economic policy, namely: First, public spending relative to real GDP (GOV), second, foreign direct investment relative to real GDP (FDI), then, trade openness in relation to real GDP (TRADE) and finally, the consumer price index (CPI). In fact, the inflation risk (CPI) is not to be discarded in case of flexible exchange. If an inflationary spiral is unlikely to settle, following a negative external shock, via a salary indexing mechanism as this is often lacking in developing countries, it can still be triggered by imported inflation, which magnitude depends only on the rate of penetration and the import price elasticity and/or the low productivity that characterizes the economies of these countries. As a matter of fact, these countries are far from the technological frontier. Moreover, public spending (GOV) has traditionally been seen as a stimulus for economic growth (Nubukpo, 2007). Indeed, according to the Keynesian logic, public spending can exert a significant countercyclical influence on the economies fundamental variables, especially on consumption and investment. Moreover, in monetary unions, the fiscal policy is the main instrument for responding to the various asymmetric shocks that may affect economies in the absence of a fiscal federalism, since the monetary policy is common to all the countries. The foreign direct investment relative to real GDP (FDI) is another internal characteristic to be considered when assessing the ability of a particular exchange rate regime to generate growth but received very little attention in the economic literature.

The FDI variation would theoretically have two opposite effects on real output, depending on the flexibility degree of the exchange rate regime: on the one hand, a net FDI inflow into a flexible regime leads, ceteris paribus, to an appreciation of the exchange rate and a mastery of the imported inflation favorable to consumption and therefore to growth; on the other hand, if the Marshal-Lerner condition is checked, this exchange rate appreciation ultimately reduces production by undermining cost competitiveness. In fixed exchange, the adjustment is made by the interest rate, which reacts to decline and consequently favors investment. Trade openness (TRADE) has been defined in the economic literature by several authors in various ways. However, the most agreeable definition considers trade opening as the progressive reduction of customs duties and the elimination of other restrictions on the free movement of goods and services. In order to estimate it, most international organizations (IMF, World Bank, among others) use the trade opening rate measured by the ratio of the sum of exports and imports to gross national product.

The second group of explanatory variables forms monetary variables related to GDP, namely the monetary aggregate (M3) and the private credit (CREDIT), which represents the degree of development of the financial sector whose effects are expected to be positive on growth. The first indicator M3 most widely used is the ratio of the monetary aggregate or liquid liabilities of the economy to GDP, i.e. M3/GDP. It is undoubtedly the most widely used indicator in this field (Jung 1986, Berthélemy and Varoudakis 1996a, 1996b, Arestis and Demetriades 1998, Bakhouche 2007). This ratio reflects the size of the financial system vis-à-vis the overall size of the economy, i.e. financial deepening. Levine (1997), Gertler and Rose (1994), Roubini and Sala-i-Martin (1992) found that there is a strong positive correlation between this indicator and the per capita GDP. The higher the value of this ratio, the more the financial system is developed, notably through the expansion of savings mechanisms, the increase in the size of the banking sector, the improvement of the provision of financial services, and the increase of liquidity in the economy. The second indicator (CREDIT) measures the financial intermediation and is equal to the ratio between the amount of credit granted to private enterprises (by deposit banks in general and non-banking institutions as an accessory) and GDP. Excluding the public sector, this indicator illustrates how funds are channelled to private investors. Levine (1997) finds a statistically significant positive correlation between real GDP per capita and the way credit is directed to the private sector. This indicator isolates credits to the private sector from credits allocated to the government and public enterprises. However, it is often influenced by directed credit policies or government grant programs.

The third group of the explanatory variables forms exchange rate variables, namely the real effective exchange rate (REER). As for the risk of financial instability inherent to the exchange rate 
volatility in a flexible regime and its negative impact on the real economy, Aghion et al. (2009) think of it as dependent on firms' ability to finance and invest in order to improve their productivity. The authors clearly differentiate the case of developing countries with a shallow financial market and the risk-averse financing institutions in developed countries. For a set of countries, Aghion et al. (2009) show that productivity is negatively related to the degree of flexibility of the exchange and consider it preferable to the adoption of a fixed regime.

From the above, the final model to be estimated, after linearization by natural logarithm, can be defined as follows:

$$
\begin{gathered}
\operatorname{LnGDPC}_{i t}=\beta_{0}+\beta_{1} \operatorname{LnPOP}_{i t}+\beta_{2} \operatorname{LnGFCF}_{i t}+\beta_{3} \operatorname{LnFDI}_{i t}+\beta_{4} \operatorname{LnREER}_{i t}+\beta_{5} \operatorname{LnCPI}_{i t} \\
+\beta_{6} \operatorname{LnTRADE}_{i t}+\beta_{7} \operatorname{LnM}_{i t}+\beta_{8} \operatorname{LnGOV}_{i t}+\beta_{9} \operatorname{LnCREDIT}_{i t}+u_{i t}
\end{gathered}
$$

where " $L n "$ represents the natural logarithm. We present a summary of the main descriptive statistics in table 1 below.

According to the left side of figure 1, it is clear that the GDP per capita (GDPC) is characterized by an upward trend for all the countries, but with a great difference between Libya and the other 4 countries. For example, during the 1980/2019 period, Libya has an average of 8014.3 with a standard deviation of 1914.1. All of its values are between 4539.0 and 12064.8 with a strong concentration around 7755.5. In addition, the sample distribution of GDPC is skewness spread on the right (Skewness $=0.603$ ) and leptokurtic (Kurtosis $=2.58)$. In total, this variable shows an overall growth of $28.8 \%$ with an annual growth of $0.71 \%$.

FDI relative to GDP is very noticeable in Mauritania compared to the other countries. In fact, the right-hand side of figure 1 shows a significant increase of FDI for Morocco at the start of the study period and a considerable growth for Mauritania between 2010 and 2019. In fact, for the case of Mauritania, the FDI evolution is characterized by an average of 2,952 with a too large standard deviation of 6.76 which makes its coefficient of variation is too high greater than $1(=2.29)$. All values for this country are between 0.01 and 37.17 . The FDI sample distribution is asymmetrically spread on the right (Skewness $=3.93$ ) and also strongly leptokurtic (Kurtosis $=18.91)$. Overall, this variable shows significant overall growth of $49.72 \%$ with annual growth of $1.13 \%$.

Regarding the real effective exchange rate (REER), the evolution of the 5 countries in the left-hand side of figure 2 shows a clear difference until the beginning of the 1990s. Moreover, we observe the stability of rates around $100 \%$. For the case of Tunisia, the evolution of the REER is characterized by an average of 132.1 with a standard deviation of 42.1. All values are between 78.3 and 221.0. The sample distribution of the REER is asymmetric spread to the right (Skewness $=1.11$ ) and largely leptokurtic (Kurtosis $=3.20$ ). In total, this variable shows a significant overall decrease of $56.82 \%$ with an annual decrease of $-2.31 \%$.

Trade openness (TRADE) increased considerably from the 2000s in all countries and reached record rates like Libya in 2012 of $138.9 \%$ relative to GDP. According to the right-hand side of Figure 2, and for the case of Morocco, the evolution of TRADE is characterized by an average of 47.2 with a standard deviation of 12.3. All values are between 30.8 and 67.8. The sample distribution is asymmetric spreading slightly to the right (Skewness $=0.40$ ) and leptokurtic (Kurtosis $=1.73$ ). In total, this variable shows a significant global growth of $282.2 \%$ with an annual growth of $3.44 \%$.

On the whole, we found that the majority of the series are on average unstable in mean or in variance. In addition, they showed a strong divergence from one country to another, which proves once again the strong heterogeneity and dependence between them.

\section{Results and discussion}

It should be noted that the applied approach is the same as the PTR model. Hence, the evaluation is carried out in two phases. The first admits to discard the individual fixed effects while the second 
tests the parameters by the non-linear least squares. It is therefore essential to extract the individual means of equation (1) while taking into consideration the threshold parameter $c$ and the smoothing one $\gamma$.

After removing individual effects, the assessment procedure is similar to that of the STAR models. In fact, the various parameters of the model are tested using non-linear least squares method. This is to reassert the sum of the residual squares of the PSTR model with respect to the slope parameters and the threshold and smoothing coefficients. More precisely, for a pair $(\gamma, c)$, it is possible to evaluate the extreme regime slope parameters using the least squares $\hat{\beta}(\gamma, c)$. Subsequently, regarding $\hat{\beta}(\gamma, c)$, the coefficients of the change function $\gamma$ and $c$ are evaluated using the non-linear least squares method, as shown by the program below:

$$
(\hat{\gamma}, \hat{c})=\arg \min \sum_{i=1}^{N} \sum_{t=1}^{T}\left[\tilde{y}_{i t}-\hat{\beta}^{\prime}(\gamma, c) \cdot \tilde{z}_{i t}^{*}(\gamma, c)\right]^{2}
$$

Based on estimators of $\gamma$ and $c$, it is feasible to evaluate again the slope parameters using $\hat{\beta}(\gamma, c)$. Hence, when the losses are assumed to be normally distributed, this estimation method is equivalent to an accumulated maximum likelihood procedure. The linearity test or the test of homogeneity on the panel data conceives an indispensable phase of the analysis. In a first evaluation, to expose the procedure, it is possible to put oneself within the framework of a PSTR model (equation 1) with a single logistic transition function of order $m$ (equation 2) and a transition variable $q_{i t}$ is proven. As with the STAR models, there are two sets of feasible hypotheses to symbolize the null hypothesis: $H_{0}: \beta_{1}=0$ versus $H_{1}: \beta_{1} \neq 0$ or $H_{0}: \gamma=0$ versus $H_{1}: \gamma \neq 0$.

It should be noted, however, that the support of the smoothing coefficient $\gamma$ is no longer finite, besides, the dispersion between the threshold coefficient and the change variable suggests the value of the transition function, therefore, it is no longer feasible to find a solution for the program (8) by dusting on an interval identical to the PTR model. We are then obliged to use a numerical optimization algorithm.

\subsection{PSTR threshold effect of FDI on economic growth}

We start this part with the linearity test to check if the threshold impact is statistically significant and the function linking the exogenous variable to the endogenous can be symbolized from a regime change model. In fact, there are two possible hypotheses that represent the one of no regime change that can be tested according to the Wald Lagrange Multiplier statistics, which follows a usual chi-square distribution:

$$
L M=T N\left(R S S_{0}-R S S_{1}\right) / R S S_{0}
$$

where $R S S_{0}$ is the panel residual sum of squares of a linear panel model with individual effects and $R S S_{1}$ is the panel residual sum of squares of a nonlinear panel model with two regimes. Under the null hypothesis, the Wald LM statistics is distributed according to a chi-square distribution with $k$ degrees of freedom where $k$ is the number of explanatory variables. Then, $T$ and $N$ represent the number of observations per country and the number of countries, respectively. On another level, we can use the Likelihood ratio (LR) test that can be written as:

$$
L R=-2\left[\operatorname{Ln}\left(R S S_{1}\right)-\operatorname{Ln}\left(R S S_{0}\right)\right]
$$

Under the null hypothesis, the LR statistics is distributed according to a chi-square distribution with $k$ degrees of freedom where $k$ is the number of explanatory variables.

Likewise, the corresponding Fisher Lagrange Multiplier (LMF) statistics is then defined by:

$$
L M F=\left[\left(R S S_{0}-R S S_{1}\right) / 2\right] /\left[R S S_{0} /(N T-N-2)\right] \rightarrow \chi^{2}(2)
$$

Under the null hypothesis, this statistics follows a Chi-2 distribution with two degrees of freedom. 
We then estimate the impact of FDI on economic growth using the PSTR model and start with the linearity test with which we check whether the order $m$ is equal to 1 or not. The results of the test of the specification (1) are presented in table 2.

This table shows the p-value of the Lagrange Multiplier (LM), Fisher Lagrange Multiplier (LMF) and the Likelihood Ratio test (LR) statistics for the null hypothesis of linearity compared to the alternative of the logistic PSTR specification $(m=1)$ or $(m=2)$. We found that the null hypothesis of linearity is rejected at the $1 \%$ significance level. Moreover, the rejection of the linearity is stronger for $m=2$, therefore, the logistic specification $(m=2)$ is preferred to $(m=1)$. These results imply that there is a non-linear relationship between FDI and economic growth in the Maghreb countries. We therefore use the estimation of the nonlinear growth model using the PSTR estimate.

In fact, linearity testing is only a first step before finalizing the PSTR model while the determining of the optimal number of transition functions is another important step in identifying the number of regimes that describe the dynamics of the relationship between FDI flows and economic growth. In fact, we set the maximum number of regimes to two. On the other hand, the PSTR estimate must test the remaining non-linearity presented in Table 3. Actually, we have strong evidence on the existence of a threshold in the model. In the first case, the null hypothesis of a single threshold $(\mathrm{r}=1)$ is rejected at the meaning level of $1 \%$ for both tests. Then, in the second case, the hypothesis with at least two thresholds ( $r=2)$ is accepted. This means that in the context of the Maghreb countries, the relationship between FDI and economic growth has only two thresholds and 3 regions. Therefore, it is clear that the order of $m=2$ is preferred to $m=1$.

Table 4 presents the test results for the existence of the threshold value and provides information on the transition parameter. The RSS, AIC and BIC minimizing values are reached at LnFDI values equal to 1.893 and 4.813 for $\mathrm{m}=2$, which is converted into an exponential at 6.639 and 123.1. The results suggest that, for the two estimated threshold values, the transition parameters $\gamma$ are 0.909 and 4.307 .

Figure 3 shows the two transition functions with respect to the transition variable (FDI). The first figure on the left suggests that the shift from a high FDI to a low FDI regime is gradual because the value of $\gamma$, which is equal to 0.909 , is very low. On the other hand, the second figure on the right suggests that switching from one high FDI to another strong one is relatively gradual with a Ushaped curve because the value of $\gamma$ is slightly low, 4.307.

We use PSTR estimation model by applying non-linear least squares method to the data in order to eliminate individual effects. Table 5 presents the PSTR estimate of the three regimes for the five Maghreb countries over the $1980 / 2019$ period. We found that the effect of FDI on growth is nonlinear. In fact, for a low FDI-to-GDP regime (LnFDI<1.863, i.e. FDI<6.443), FDI elasticity is estimated at -0.070 and is statistically significant.

For an average FDI regime $(1.893<\mathrm{LnFDI}<4.813$, i.e. $6.639<\mathrm{FDI}<123.1)$, the coefficient of elasticity of FDI is estimated at 0.045 and statistically significant at 5\%. For a strong FDI regime (LnFDI $>4.813$, i.e. FDI $>123.1$ ), the coefficient of elasticity of FDI is estimated at 0.029 but statistically, it is weakly significant. On the other hand, the threshold of 4.813 is well above 1.893 , which is that of Tunisia and Morocco compared to other countries. Although the second coefficient is almost equal to the threshold of the PTR model, the impact of FDI is low. Based on the PSTR, there is a slightly favorable effect on economic growth, especially after the second threshold. Below the first threshold, an increase of FDI leads to an increase of growth. On the other hand, a decline of FDI below the first threshold causes a decline of economic growth.

In fact, the vast majority of Southern Mediterranean countries (SEMCs) have attracted a little capital. For this reason, two explanations are generally given. The first is that these countries are facing challenges related to FDI and therefore, they favored strategies to substitute for imports (Morocco) or industries (Algeria); which led to a low international integration. The second 
explanation is that, in addition to their low overall factor of productivity (Youssef, 2004), these countries have long suffered from macroeconomic, political and institutional instability.

Since the late 1980s and early 1990s, the perceptions of FDI by these nations have dramatically changed to what Michalet (1999) has called a "big turnaround". There is a gradual process of "seduction" policies, which indicate that the leaders of these countries are now linking FDI to the economic growth dynamics. Nearly all the Maghreb countries are now trying to attract FDI through various and varied "incentives", such as macroeconomic stabilization, exchange rate policies and the signing of partnership agreements with Europe, tax exemption or the establishment of free zones, privatization sanctioning the withdrawal of the State from some sectors of activity, or institutional reforms aimed at improving the business climate. The range of incentives is now long and relevant. Almost twenty-five years after the 1995 Barcelona Agreements and thirty years after the start of attractiveness policies in the area, the question about the effectiveness of these measures in terms of growth dynamics was raised.

In this part, we have tried to establish a link in the case of the Maghreb countries between the received investment flows, the dynamics of these structural factors and the growth dynamics from 1980 to 2016. We show, in particular, that among these structural factors, several monetary variables showed their positive and especially negative influence on economic growth, including inflation and money supply.

The question about the conditions enabling FDI to promote the economic of the host economies is essential. By promoting attractiveness policies for foreign investment, the developing countries are in fact betting that the FDI they wish to host could stimulate their economic growth and technological catch-up. However, these policies, which have a high social cost in terms of tax revenue or increased competition, produce economic benefits only under certain conditions. We show here that these conditions are related to several structural factors of the developing economies: firstly, their level of human and financial capital and the degrees of trade openness and financial development. Structural factors identified in the literature as complementary to FDI (commercial openness, human capital, financial development) are generally mobilized in attractiveness policies.

On the other hand, the microeconomic incentive policies, which are often at the heart of attractiveness policies, are socially optimal only if they intervene at an already advanced stage of the structural development of an economy or if they are integrated into broader strategies aiming developing in parallel all the factors that are complementary to FDI in the determination of economic growth.

The results generated by this study showed that FDI in the Maghreb countries has a fairly positive effect on economic growth above the first threshold, but remains an approximation to keep it in the long run. The indifferent impact was noticed on all exogenous variables, namely the domestic investment, the human capital and consequently economic growth. We can conclude that the contribution of FDI to economic growth is very clear, notwithstanding the eviction effect that has generated the FDI on household investment.

\subsection{PSTAR threshold effect of FDI on economic growth}

For all the five countries, we propose to estimate a PSTAR model to calculate the transition speed of a recession regime (where GDP growth is negative) towards a growth regime (where GDP growth is positive); and secondly, to endogenously determine the FDI threshold around which their volatilities exert two different levels of influence on GDP growth. For this reason, we first apply the Terasvirta approach (1994, p.10) to a panel data context. We then use the approach of Colletaz and Hurlin (2006), once the PSTAR model is estimated, to test the non-linearity of this model.

The Terasvirta's approach consists in specifying a linear autoregressive model for economic growth (GDPC). In a panel data context, estimating a linear model with autoregressive terms requires the use of the General Method of Moments with instrumental variables (GMM-IV) to avoid the endogenous bias resulting from the dummy variables (representing the effects fixed-country) 
affecting the dependent variable over the entire period. Following the procedure of Arellano and Bover (1995), which consists in differentiating the instruments in order to make them exogenous to fixed effects and thus eliminate the problem of endogeny, we can write:

$$
\begin{aligned}
\operatorname{LnGDPC}_{i t} & =\beta_{i}+\sum_{i=1}^{p} \alpha_{i} \operatorname{LnGDPC}_{i t-1}+\beta_{1} \operatorname{LnPOP}_{i t}+\beta_{2} \text { LnGFCF }_{i t}+\beta_{3} \operatorname{LnFDI}_{i t}+\beta_{4} \text { LnREER }_{i t} \\
& +\beta_{5} \operatorname{LnCPI}_{i t}+\beta_{6} \operatorname{LnTRADE}_{i t}+\beta_{7} \operatorname{LnM}_{i t}+\beta_{8} \operatorname{LnGOV}_{i t}+\beta_{9} \operatorname{LnCREDIT}_{i t}+\varepsilon_{i t}
\end{aligned}
$$

with $\beta_{i}$ representing the fixed-country effects and $\varepsilon_{i t}$ designating the error term.

To search for the order of this self-regression, the model (12) is estimated sequentially starting with a maximum of 4 lags and selecting the number of lags for which the coefficients of the lagged endogenous variable are statistically significant at a significant coefficient of 5\%. Through this technique, we obtain a lag number $p=3$. The estimation of equation (12) is given in Table 6 .

Using the GMM-IV method following the Wald test, we notice that the estimated coefficients of the LnGDPC variable, which are delayed by three periods, are statistically significant at a significant coefficient of 5\%. Since the model is statistically validated, we consider that the PSTAR model has three lags, we start by taking the LnFDI variable as a transition variable. On the other hand, and in reference to Verne (2016), the value of the residual sum of squares (RSS) is included in the calculation of the LMF statistics (equation 12 above), which was developed by Colletaz and Hurlin (2006, p.11) and used for the non-linearity test applied to the PSTAR model defined by equation (13) below:

$$
\begin{aligned}
& \operatorname{LnGDPC}_{i t}=\beta_{0}+\sum_{j=1}^{3} \alpha_{1 j} \operatorname{LnGDPC}_{i t-1}+\beta_{11} \operatorname{LnPOP}_{i t}+\beta_{21} \operatorname{LnGFCF}_{i t}+\beta_{31} \operatorname{LnFDI}_{i t}+\beta_{41} \operatorname{LnREER}_{i t} \\
& +\beta_{51} \operatorname{LnCPI}_{i t}+\beta_{61} \operatorname{LnTRADE}_{i t}+\beta_{71} \operatorname{LnM}_{i t}+\beta_{81} L n G_{i t}+\beta_{91} \operatorname{LnCREDIT}_{i t}+ \\
& \left(\begin{array}{l}
\sum_{j=1}^{p} \alpha_{2 j} \operatorname{LnGDPC}_{i t-1}+\beta_{12} \operatorname{LnPOP}_{i t}+\beta_{22} \operatorname{LnGFCF}_{i t}+\beta_{32} \operatorname{LnFDI}_{i t}+\beta_{42} \operatorname{LnREER}_{i t}+\beta_{52} \operatorname{LnCPI}_{i t} \\
+\beta_{62} \operatorname{LnTRADE}_{i t}+\beta_{72} \operatorname{LnM}_{i t}+\beta_{82} \operatorname{LnG}_{i t}+\beta_{92} \operatorname{LnCREDIT}_{i t}
\end{array}\right) \\
& \times\left(1+\exp \left[-\gamma\left(\operatorname{LnFDI}_{i t}-c\right)\right]\right)^{-1}+\varepsilon_{i t}
\end{aligned}
$$

Let $G\left(\operatorname{LnFDI}_{i t} ; \gamma, c\right)=(1+\exp [-\gamma(\operatorname{LnFDI}-c)])^{-1}$ indicating the transition function where $G \in[0 ; 1]$, $\gamma>0$ is the smoothing parameter that determines the speed of transition from one regime to another and $c=\left(c_{1} c_{2} \Lambda c_{m}\right)^{\prime}$ is a vector of dimension $m$ including the threshold parameters where $c_{1} \leq c_{2} \leq \Lambda \leq c_{m}$.

From the estimation in Table 6, we now proceed to the estimation of the relation (12), via the nonlinear least square method, which gives us the results of Table 7.

The value of LMF statistics and its probability in brackets, which is associated with it, leads us to strongly reject the null hypothesis of linearity $(L M F=2.858$, p-value $=0.0007)$. In addition, the majority of the coefficients are statistically significant at the $1 \%, 5 \%$ and $10 \%$ levels. On the other hand, Fisher's statistics and its probability indicate that the regression is globally significant at the $5 \%$ level. We also noted that the threshold value $c$ equal to 0.909 , means that the threshold of FDI as a percentage of GDP around which FDI volatilities exert two levels of impact on growth, reaches $2.482 \%$.

$\gamma$ indicates the slope of the logistic function and thus governs the speed with which the transition takes place between the recession regime $(G=0)$ and the growth regime $(G=1)$. The proportionally high value of the coefficient $\gamma$ equal to 20.433 means that the economies of the Maghreb countries move quite abruptly from a recession to a growth regime as shown in Figure 4. This graph shows a transition from a recession to a very brutal growth regime within which the 
majority of countries, with the exception of Libya and Algeria, represent this phenomenon. There is also an asymmetry in the growth evolution of the five countries. Indeed, the final model shows that when FDI is below its threshold value of $2.482 \%$, the existence of a low external investment leads to a drop of economic growth by $0.55 \%$ against a growth of about $0.6 \%$ when FDI becomes higher than its threshold value.

In fact, one of the limitations of previous studies in this area is their insufficient effort to better understand how FDI can interact to explain the variation in economic growth. Therefore, the impact of FDI on economic growth is likely to depend on the adopted trade regime.

In this context, countries with a liberal trade regime could perform better in attracting FDI and using it as a catalyst for economic growth. A liberal trade regime could create an investmentgenerating investment climate, which is in symbiosis with human capital and new technologies brought about by FDI. In addition, trade openness could enhance access to larger markets and could therefore seemingly help attract more FDI. In a context of trade liberalization, FDI could make a significant contribution to the transfer of modern technology and innovation from the developed to the developing countries and, as a result, could boost trade and economic growth.

We would like to point out that our empirical results showed that FDI flows have a ripple effect on the per capita economic growth in a situation where it is accompanied by trade liberalization. According to our estimates and tests, an improvement of the interaction between FDI and onepercentage point trade liberalization would increase the per capita economic growth. This means that FDI flows and trade liberalization interact to determine the per capita economic growth, but this combined effect seems to require more time to boost the real output per capita because the variable that measures the interaction between FDI and trade liberalization is stationary in level and therefore its short-term impact is non-operational.

\section{Conclusion and policy implications}

The purpose of this study is to examine the non-linear effect of FDI on economic growth in the AMU countries during the period 1980-2019. Accordingly, we discussed two broad approaches that result from either an observable or unobservable shift factor. It is particularly the initial approach relating to threshold models which has received a great deal of interest in panel data compared to Markov regime change models. Therefore, the PSTR smooth change approach of González et al. (2017) and the smooth transition allowing a PSTAR an autoregressive mechanism of Fok et al. (2005) are observed, where the possibility of an average regime is modeled with the introduction of a transition mechanism.

The results highlight the asymmetrical effect of unforeseen shocks on the adopted FDI level. The relationship with opening from FDI is more complicated than it looks. This complication is due, particularly but not exclusively, to the close relationship between FDI and the characteristics of host economies. It is fundamentally to the host economies that they are trying to put in place general, transparent and investment-friendly stipulations, and to support the human and institutional skills essential for foreign capital flows to be able to have real impacts on growth.

FDI contributes positively to the growth and development of the AMU countries, by strengthening the degree of competition of these economies and by encouraging local companies to acquire technologies and / or adopt more competitive production methods. This is based on the premise that countries that receive FDI in a stable manner over time are most likely, under certain conditions, to improve their productive capacity. The results obtained made it possible to highlight a heterogeneity of the links studied in the Maghreb economies, despite the existence of some features of similarity. The link between FDI and growth has only been observed over a long period for Algeria and Tunisia. Even then, its scale and significance disappear in the long run. So, to benefit from the positive externalities of FDI, trade transactions in Maghreb countries should continue to be oriented towards a further liberalization. In the framework of the Euro-Mediterranean free trade area, FDI flows to these countries are expected to contribute to economic growth, particularly in the long run. 


\section{Ethics approval and consent to participate}

The authors of the paper attest that this article does not contain any studies with human participants or animals performed by any of the authors.

\section{Consent for publication}

(a) Neither the article nor portions of it have been previously published elsewhere (except as an abstract or as part of a dissertation),

(b) The manuscript is not under consideration for publication in another journal, and will not be submitted elsewhere until the JECS editorial process is completed, and

(c) All authors consent to the publication of the manuscript in JECS, should the article be accepted by the Editor-in-chief upon completion of the refereeing process.

\section{Availability of data and materials}

Data are collected from the World Bank 2020 database and the central banks of Tunisia, Morocco, Algeria, Mauritania and Libya.

All the empirical applications were run using Stata 15 and Matlab 2013 software.

\section{Competing interests}

We declare that have no conflict of interest.

\section{Funding}

No funding to declare: The authors received no specific funding for this work.

\section{Authors' contributions}

The authors contribute to test the existence of a non-linear relationship between economic growth and FDI through the explanation of the asymmetry of the impact (mixed relationship, sometimes positive and sometimes negative) of FDI on economic growth for developing countries, especially for AMU countries.

\section{Acknowledgements}

Not applicable 


\section{References}

Aghion, Philippe, Philippe Bacchetta, Romain Ranciere, and Kenneth Rogoff. 2009. "Exchange Rate Volatility and Productivity Growth: The Role of Financial Development." Journal of Monetary Economics, 56(4): 494-513. http://nrs.harvard.edu/urn-3:HUL.InstRepos:12490419

Agosin, Manuel R. and Ricardo Mayer. 2000. "Foreign Investment In Developing Countries, Does It Crowd In Domestic Investment." UNCTAD Discussion Paper No. 146. https://unctad.org/system/files/official-document/dp_146.en.pdf

Arellano, Manuel and Olympia Bover. 1995. "Another Look at the Instrumental Variable Estimation of Error-Components Models." Journal of Econometrics, 68: 29-51. https://doi.org/10.1016/0304-4076(94)01642-D

Arestis, Philip, and Panicos Demetriades. 1998. "Financial Liberalization: Myth or Reality?" Chapter 11 in P. Arestis (ed.), Method, Theory and Policy in Keynes: Essays in Honour of Paul Davidson, Volume Three, Cheltenham: Edward Elgar.

Athreye, Suma and Cantwell, John. 2007. "Creating competition?: Globalisation and the emergence of new technology producers." Research Policy, Elsevier, 36(2): 209-226, March. https://ideas.repec.org/s/eee/respol.html

BAD, 2015. "Rapport annuel 2015." Groupe de la banque africaine de développement, La Banque Africaine de Développement, 2015. https://www.afdb.org/fr/documents/document/afdb-annualreport-2015-88761

Bakhouche, Abderazak. 2007. "Does the Financial Sector Promote Economic Growth? A Case of Algeria." Savings and Development, 31(1): 23-44. https://www.jstor.org/stable/25830950

Bas, Christian Le and Christophe Sierra. 2002. "Location versus home country advantages in R\&D activities: Some further results on multinationals locational strategies." Research Policy, 31: 589609. https://doi.org/10.1016/S0048-7333(01)00128-7

Ben Abdallah, A., Meddeb, F. 2001. "Interaction entre IDE, capital humain et croissance dans les pays émergents", in BOUDIAF, M. et SIROËN J.M. 2001 (eds.). Ouverture et développement économique, Paris Economica.

Ben Cheikh, Nidhaleddine., and Younes Ben Zaied. 2020. "Revisiting the pass-through of exchange rate in the transition economies: New evidence from new EU member states." Journal of International Money and Finance, DOI: 10.1016/j.jimonfin.2019.102093

Berthélemy, Jean-Claude and Aristomene Varoudakis. 1996a. "Economic growth, convergence clubs, and the Role of Financial Development." Oxford Economic Papers, 48: 300-328. https://doi.org/10.1093/oxfordjournals.oep.a028570

Berthélemy, Jean-Claude and Aristomene Varoudakis. 1996b. "Développement Financier, Réformes financières et Croissance. Une Approche en Données de Panel." Revue Economique, 46(2): 217-235. DOI:10.3406/reco.1998.409972

Berthélemy, Jean-Claude and Sylvie Démurger. 2000. "Foreign Direct Investment and Economic Growth: Theory and Application to China." Review of Development Economics, 4(2): 140-155. https://doi.org/10.1111/1467-9361.00083.

Bessec, Marie and Julien Fouquau. 2008. "The non-linear link between electricity consumption and temperature in Europe: a threshold panel approach." Energy Economics, 30, 2705-2721. https://doi.org/10.1016/j.eneco.2008.02.003

Blomström, Magnus and Edward Wolff, 1994. "Multinational corporations and productivity convergence in Mexico," in Baumol W., R. Nelson and E. Wolff (eds): Convergence of Productivity: Cross National studies. Oxford, Oxford University Press. 
Blomström, Magnus, Ari Kokko and Steven Globerman. 2001. "The determinants of host country spillovers from foreign direct investment: a review and synthesis of the literature." Inward Investment Technological Change and Growth, 34-65. Palgrave Macmillan, London. https://doi.org/10.1057/9780230598447_2

Borensztein, Eduardo, Jose De Gregorio and Jong-Wha Lee, 1998. "How does foreign direct investment affect economic growth?." Journal of International Economics, 45: 115-135. https://ideas.repec.org/s/eee/inecon.html

Bosworth, Barry P. and Susan M. Collins. 1999. "Capital Flows to Developing Economies: Implications for Saving and Investment." Brookings Papers on Economic Activity, Economic Studies Program, The Brookings Institution, 30(1): 143-180. https://www.brookings.edu/wpcontent/uploads/1999/01/1999a_bpea_bosworth.pdf

Bouoiyour, Jamal, Hicham Hanchane and El Mouhoub Mouhoud. 2009. "Investissements directs étrangers et productivité: Quelles interactions dans le cas des pays du Moyen Orient et d'Afrique du Nord?" Revue économique, 60(1): 109-132, Janvier. https://www.jstor.org/stable/25483993.

Carbonell, Jorge Bermejo, and Richard A. Werner, 2018. "Does Foreign Direct Investment Generate Economic Growth? A New Empirical Approach Applied to Spain.” Economic Geography, 94(4): 425-456. https://doi.org/10.1080/00130095.2017.1393312

Carkovic, Maria V. and Ross Levine. 2002. "Does foreign direct investment accelerate economic growth?" University of Minnesota, Working Paper. Available at SSRN: https://ssrn.com/abstract=314924 or http://dx.doi.org/10.2139/ssrn.314924

Colletaz, Gilbert and Christophe Hurlin. 2006. "Threshold effects in the public capital productivity: an international panel smooth transition approach." Document de Recherche 1, Laboratoire d'Economie d'Orléans. Working Papers halshs-00008056, HAL.

De Gregorio, Jose. 1992. "Economic growth in Latin America." Journal of Development Economics, 39(1): 59-84. https://doi.org/10.1016/0304-3878(92)90057-G

De Mello, Luiz R. 1999. "Foreign direct investment-led growth: Evidence from time series and panel data." Oxford Economic Papers, 51, 133-151. https://doi.org/10.1093/oep/51.1.133

Ekanayake, E.M., and Dasha Chatrna. 2010. "The effect of foreign aid on economic growth in developing countries." Journal of International Business and Cultural Studies, 3-11. http://www.aabri.com/manuscripts/09359.pdf

Farkas, Beatrice. 2012. "Absorptive capacities and the impact of FDI on economic growth." German Institute for Economic Research, DIW Berlin, March. https://EconPapers.repec.org/RePEc:diw:diwwpp:dp1202

Farole, Thomas and Deborah Winkler. 2012. "Foreign firm characteristics, absorptive capacity and the institutional framework: The role of mediating factors for FDI spillovers in low and middle income countries." Policy Research Working Paper, The World Bank, November. https://doi.org/10.1596/1813-9450-6265

Findlay, Ronald. 1978. "Relative backwardness, direct foreign investment, and the transfer of technology: A simple dynamic model." Quarterly Journal of Economics, 92(1): 1-16. https://doi.org/10.2307/1885996

Fok, Dennis, Dick Dijk van and Philip Hans Franses. 2005. "A multi-level panel star model for US manufacturing sectors." Journal of Applied Econometrics, 20(6): 811-827. https://doi.org/10.1002/jae.822.

Fouquau, Julien. 2008. "Threshold effects in okun's law: a panel data analysis.” Economics Bulletin, 5: 1-14. https://hal.archives-ouvertes.fr/hal-00565477 
$\mathrm{Fu}$, Xiaolan. 2008. "Foreign direct investment, absorptive capacity and regional innovation capabilities in China." Oxford Development Studies, 36(1), 89-110. https://doi.org/10.1080/13600810701848193

Gertler, M., and A. Rose, 1994. "Finance, Public Policy and Growth," in G. Caprio, I. Atiyas and J. Hanson (eds), Financial Reform: Theory and Experience, New-York, Cambridge University Press, p.13-14.

Giovannetti, G. and G. Ricchiuti, 2008. "The effects of the new patterns of FDI on growth and inequality: the case of Southern Mediterranean Countries." Economic Research Forum (ERF), Retrieved, June 1, 2008. https://www.researchgate.net/publication/228902507

Girma, Sourafel and Holger Görg. 2005. "Foreign direct investment, spillovers and absorptive capacity: evidence from quantile regressions." Discussion Paper Series 1: Economic Studies 2005, 13, Deutsche Bundesbank. https://www.econstor.eu/bitstream/10419/19521/1/200513dkp.pdf

Gohou, Gaston and Issouf Soumaré. 2012. "Does Foreign Direct Investment Reduce Poverty in Africa and Are There Regional Differences?" World Development, 40: 75-95. DOI: 10.1016/j.worlddev.2011.05.014

González, Andres, Timo Teräsvirta, Dick van Dijk and Yukai Yang. 2005. "Panel Smooth Transition Regression Models," SSE/EFI Working Paper Series in Economics and Finance 604, Stockholm School of Economics.

González, Andres, Timo Teräsvirta, Dick van Dijk and Yukai Yang. 2017. "Panel Smooth Transition Regression Models." Department of Economics and Business Economics, Aarhus University. CREATES Research Paper 2017-36.

Goodwin, Richard M. 1991. "Nonlinear Dynamics and Economic Evolution," in Niels Thygesen et al., editors, Business Cycles. https://link.springer.com/chapter/10.1007/978-1-349-11570-9_16

Hansen, Bruce E. 1999. "Threshold effects in non-dynamic panels: estimation, testing, and inference." Journal of Econometrics, 93: 334-368. https://doi.org/10.1016/S0304-4076(99)00025-1

Jung, Woo S. 1986. "Financial Development and Economic Growth: International Evidence." Economic Development and Cultural Change, 34(2): 333-46. http://dx.doi.org/10.1086/451531

Kalai, Maha and Nahed Zghidi. 2019. "Foreign Direct Investment, Trade, and Economic Growth in MENA Countries: Empirical Analysis Using ARDL Bounds Testing Approach." Journal of the Knowledge Economy, 10: 397-421. DOI: https://doi.org/10.1007/s13132-017-0460-6

Khordagui, Nagwa Hosny and Gehan Saleh. 2013. "FDI and absorptive capacity in emerging economies." Topics in Middle Eastern and African Economies, 15(1): 141-172, May. https://meea.sites.luc.edu/volume15/pdfs/FDI-Absorptive-Capacity.pdf

Kokko, Ari. 1994. "Technology, Market Characteristics and Sppilovers." Journal of development Economics, 43(5): 279-293. https://doi.org/10.1016/0304-3878(94)90008-6

Kokko, Ari. 1996. "Productivity Spillovers from Compétiton Between Local Firms and Foreign Affiliates." Journal of International Development, 8(4): 517-530. https://doi.org/10.1002/(SICI)1099-1328(199607)8:4<517::AID-JID298>3.0.CO;2-P

Kottaridi, Constantina and Thanasis Stengos, 2010. "Foreign direct investment, human capital and non-linearities in economic growth." Journal of Macroeconomics, Elsevier, 32(3): 858-871. https://doi.org/10.1016/j.jmacro.2010.01.004

Krogstrup, Signe and Linda Matar. 2005. "Foreign direct investment, absorptive capacity and growth in the Arab world." IHEID Working Papers 02-2005, Economics Section, The Graduate Institute of International Studies. http://repec.graduateinstitute.ch/pdfs/Working_papers/HEIWP022005.pdf 
Lahimer, Noomen. 2009. "Investissements directs étrangers et investissements domestiques en Afrique Subsaharienne: effet d'éviction ou de stimulation?" Université Paris-Dauphine. LED. https://basepub.dauphine.fr/handle/123456789/5842

Levine, Ross. 1997. "Financial Development and economic Growth Views and Agenda." Journal of Economie Litterature, 35(2) : 688-726. https://doi.org/10.1596/1813-9450-1678

Li, Xiaoying and Xiaming Liu. 2005. "Foreign direct investment and economic growth: An increasingly endogenous relationship." World development, 33(3): 393-407. https://doi.org/10.1016/j.worlddev.2004.11.001

Mallampally, Padma and Karl P Sauvant. 1999. "Foreign Direct Investment in Developing Countries. From the Selected Works of Karl P. Sauvant, Columbia University. Finance and Development, 36: 34-37. IMF \& INT BANK OF RECONSTRUCTION AND DEVELOPMENT.

Michalet, Charles-Albert. 1999. "Mondialisation, la grande rupture." Paris, Editions la Découverte, collection économie et entreprises.

Nubukpo, Kako. 2007. "Dépenses publiques et croissance des pays de 1'Union économique et monétaire ouest-africaine (UEMOA)." Afrique contemporaine, 2007/2 ( $\left.{ }^{\circ} 222\right)$, 223-250. https://www.cairn.info/revue-afrique-contemporaine-2007-2-page-223.htm

OCDE, 2002. "L'investissement direct étranger au service du développement optimisé les avantages minimiser les coûts." Organisation de coopérative et de développement économiques, 2002.

Romer, Paul M., 1990. "Endogenous Technological Change." The Journal of Political Economy, 98(5, Part 2): 71-102. https://www.jstor.org/stable/2937632

Roubini, Nouriel and Xavier Sala-i-Martin, 1992. "Financial Repression and Economic Growth." Journal of Development Economics, 39: 5-30. https://doi.org/10.1016/0304-3878(92)90055-E

Solow, M. Solow, 1956. "A Contribution to the Theory of Economic Growth." Quarterly Journal of Economics, 70: 65-94, February. https://doi.org/10.2307/1884513

Teräsvirta, Timo and Heather M. Anderson. 1992. "Characterizing Nonlinearities in Business Cycles Using Smooth Transition Autoregressive Models." Journal of Applied Econometrics, 7: 119-136. https://doi.org/10.1002/jae.3950070509

Teräsvirta, Timo. 1994. "Specification, estimation and evaluation of Smooth Transition Autoregressive Models." Journal of the American Statistical Association, 89: 208-218. https://doi.org/10.1080/01621459.1994.10476462

Verne, Jean-François. 2016. "Instabilités politiques, guerre et croissance économique : le cas du Liban et des pays du moyen-orient." Revue d'économie politique, 2016/6, 126,1077-1103. ISSN 0373-2630

Zenasni, Soumia and Abderrezzak Benhabib, 2013. "The Determinants of Foreign Direct Investment and Their Impact on Growth: Panel Data Analysis for AMU Countries." International Journal of Innovation and Applied Studies, 2(3): 300-313, March 2013. https://hal.archivesouvertes.fr/hal-00817626. 
Figures
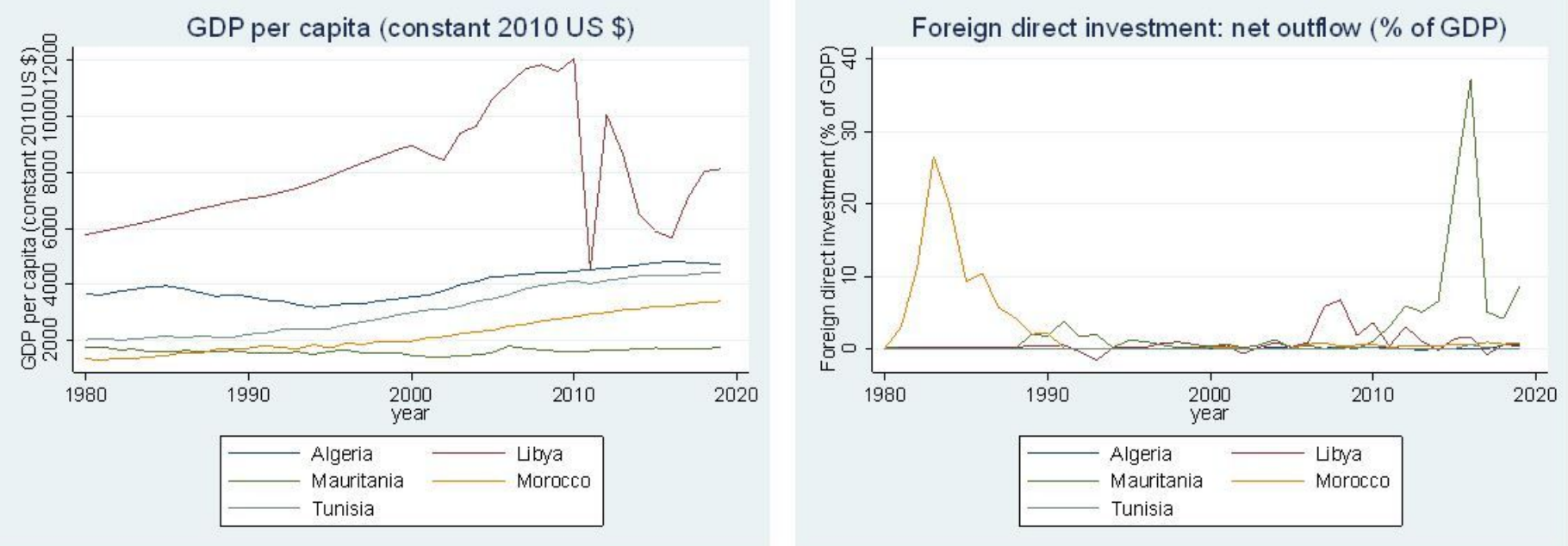

Figure 1

Trend evolution of the GDP per capita and the net outflow FDI by country
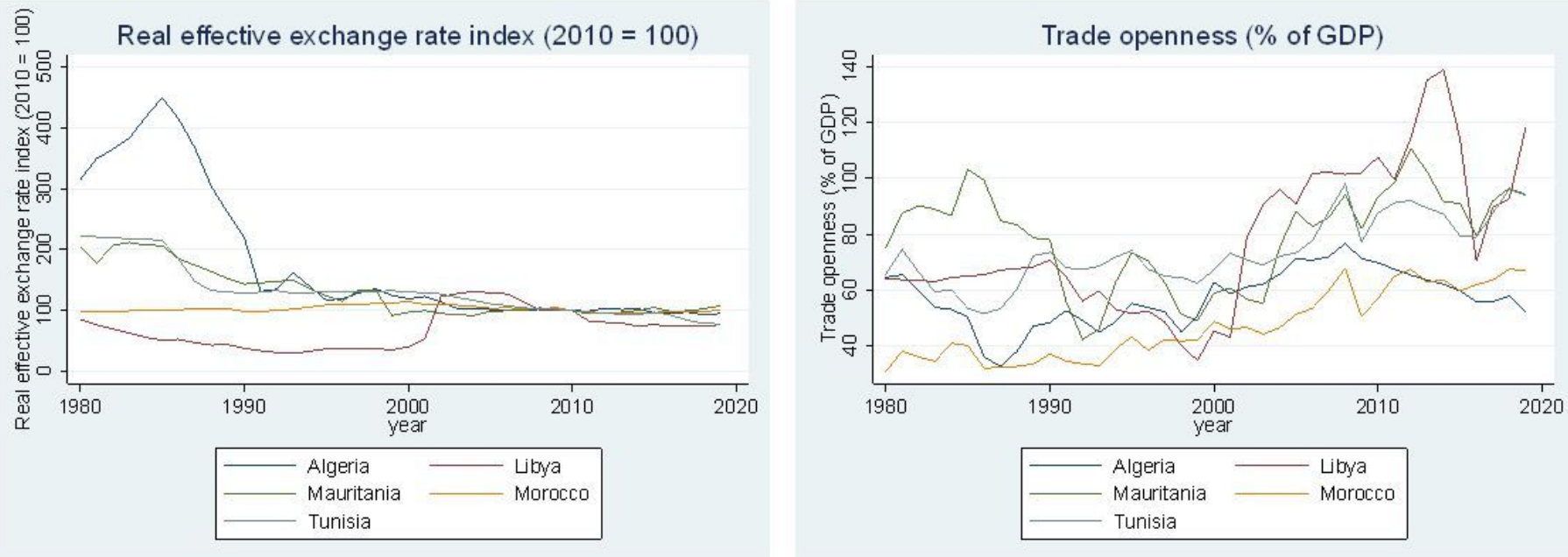

Figure 2

Trend evolution of the REER and the TRADE by country 

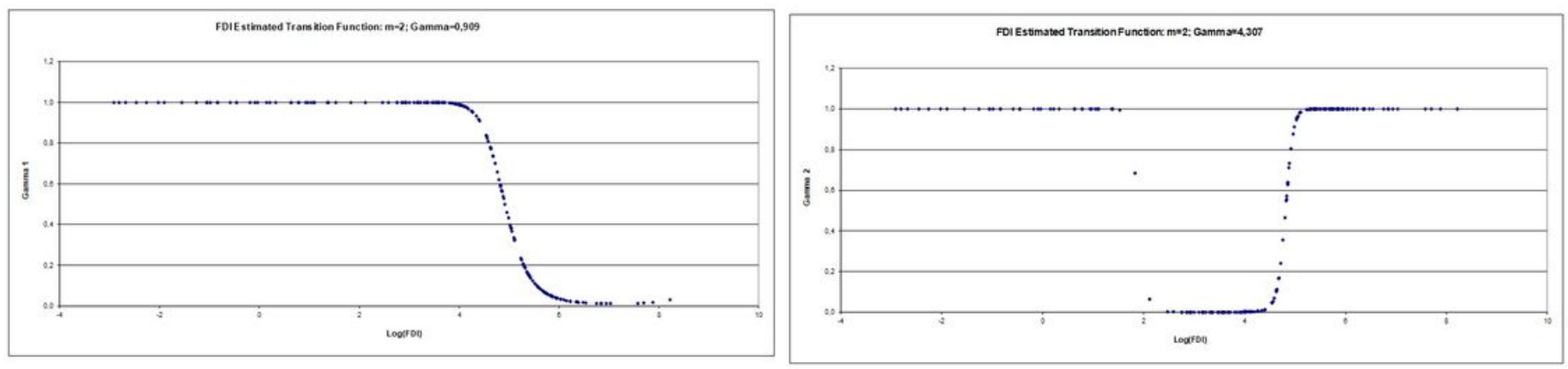

Figure 3

Estimated transition function of the PSTR model

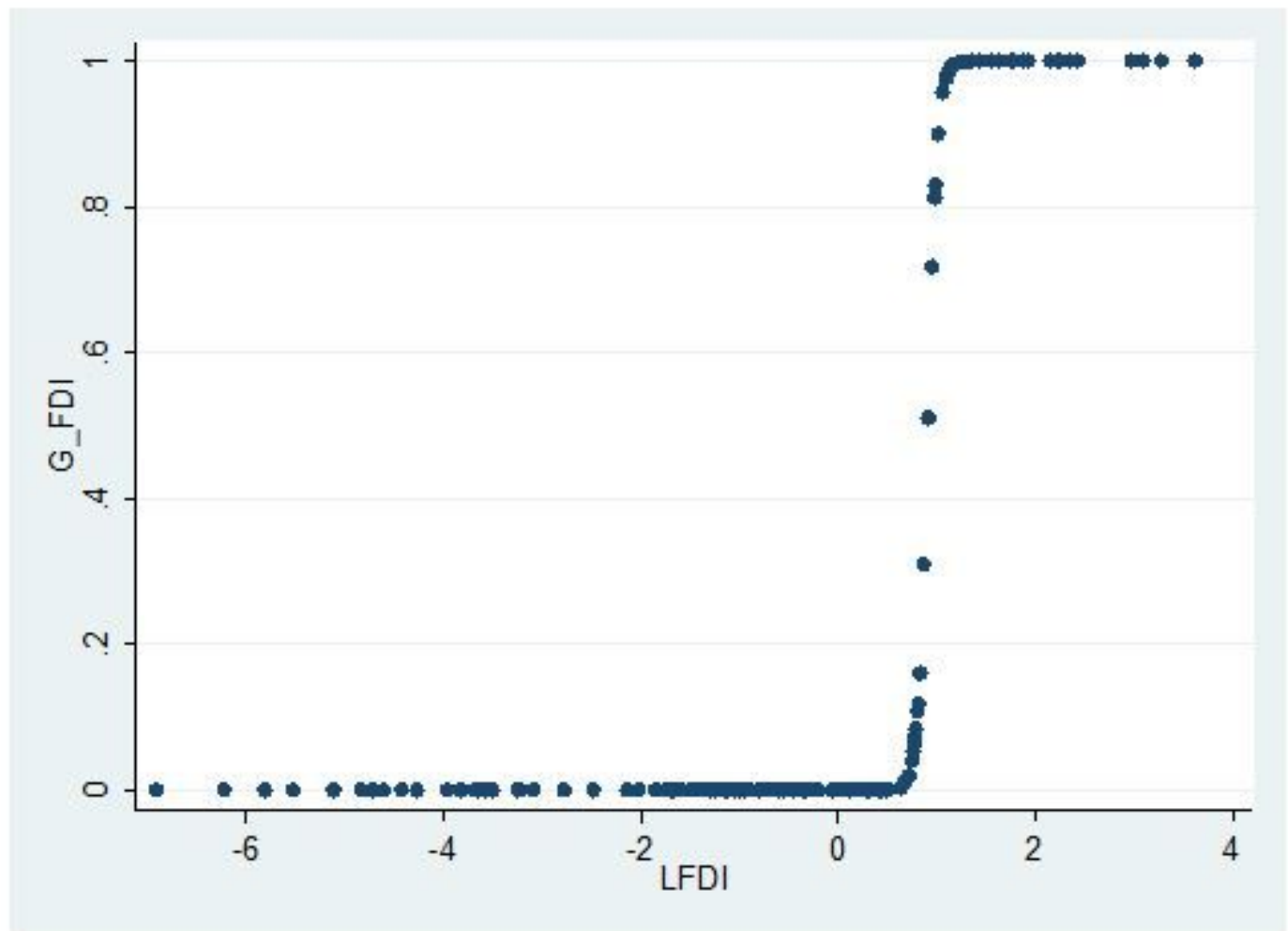

Figure 4

Estimated transition function of the PSTAR model 